$(\mathrm{n}=275)$. Increase in the number of spermatozoa $\left(12.10^{\circ} \mathrm{spz} / 21 \mathrm{~A}\right)$, improved fertility and litter size.

After drying off, a short Regumate treatment ( 3 days) was applied (starting on the day of weaning). Even in good management conditions, this treatment improved the synchronization of heats obtained after weaning. In primiparous females, whose return to oestrus after drying-off gives rise to most problems a marked improvment was noticed : 72 p. 100 of oestrus between day 5 and 7 post treatment versus 39 p. 100 in the controls. The farrowing rate after artificial insemination in connection with induced heats was comparable to that of the control sows. The dose of progestagen used $(20 \mathrm{mg} / \mathrm{d} / \mathrm{sow})$ had no unfavourable effect on litter size, but this seemed to be the case with a higher dose.

\title{
In vitro study of some factors improving spermatozoa survival during long semen storage
}

\author{
M. PAGUIGNON *, J.L. DACHEUX $* *$, M. COUROT $* * *$ \\ * I.T.P., I49, rue de Bercy, F 75595 Paris Cedex 12 \\ *: Faculté des Sriences, Laboratoire de Physiologite comparée, \\ F 37200 Tours \\ *:*: I.N.R.A.. Stction de Physiologie de la Reproduction, \\ F 37380 Monnaie
}

\begin{abstract}
Two experiments were carried out to determine the effect of the $\mathrm{Na}+/ \mathrm{K}+$ ratio of the extender and the effects of semen collection rhythm and rate of extension upon in vitro spermatozoa survival during a long storage. In the first experiment the $\mathrm{Na}+/ \mathrm{K}+$ ratios (50 - $5-0.5-0.05$ ) were compared after 48 and 120 hours of preservation at $+15^{\circ} \mathrm{C}$. In the second experiment, we compared two spermatozoa concentrations (30 and 120 $\times 10^{6} \mathrm{spz} / \mathrm{ml}$ ) as well as two rhythms of collection (once or twice a week), after 1, 2, 3,4 and 5 days of storage at $+15^{\circ} \mathrm{C}$.
\end{abstract}

An optimum $\mathrm{Na}+/ \mathrm{K}+$ ratio was determined for spermatozoa survival. This ratio, ranging between 0.5 and 5 , corresponded to that observed in the fluid of the epididymal caudal region. This optimum was more marked after 5 than after 2 days of preservation.

A low dilution $\left(120 \times 10^{i 1} \mathrm{spz} . / \mathrm{ml}\right)$ as well as the rhythm of semen collection twice a week favoured the spermatozoa survival during a long storage.

\section{Effect of the extender, rate of extension and seminal plasma or the fertility of sows after a long semen storage}

\author{
M. PAGUIGNON *,F. BARITEAU **, J. BUSSIERE ** \\ J.L. DACHEUX $* * *$, M. COUROT $* * *$ \\ * I.T.P., 149, rue de Bercy, F 75595 Paris Cedex 12 \\ ** I.N.R.A.-S.E.I.A., F 86480 Rouille \\ *.: I.N.R.A., Stction de Physiologie de la Reproduction, \\ F 37380 Monnaie
}

Two experiments were made to test the efficiency of several factors in maintaining the fertilizing ability of spermatozoa after 5 days of preservation. Guelph and $\mathrm{BL}_{1}$ extenders were compared in the first experiment. In the second one (factorial $2 \times 2$ ) the effects of two rates of extension ( 30 and $120 \times 10^{4} \mathrm{spermatozoa} / \mathrm{ml}$ ) and of two fractions of ejaculates (total fraction and rich fraction), were studied. A total of 963 and 1071 sows, respectively were inseminated once during oestrus in the first and in the second experiment. 
Guelph's extender as compared to $\mathrm{BL}_{1}$ significantly improved sow fertility after 3 days of storage $\left(72.4\right.$ p. 100 versus 62.5 p. 100 for Guelph and $B L_{1}$, respectively $(\mathrm{p}<0.001)$. Use of Guelph's extender might allow to preserve semen until 4 days after collection without any sudden decrease in fertility and prolificacy.

Fertility was significantly improved when using the total fraction of ejaculate instead of the rich one $(67.9$ p. 100 versus 60.7 p. 100) $(p<0.02)$. It was also significantly improved when using a strong dilution instead of a weak one $(67.2$ p. 100 versus 61.2 p. 100 for 30 and $120 \times 10^{\prime s} \mathrm{spz} / \mathrm{ml}$, respectively $(\mathrm{p}<0.05)$.

The semen preparation technique now used in the French A.I. centres, i.e. collection of the total ejaculate fraction diluted in Guelph's extender and split into ready-to-use doses of $100 \mathrm{ml}$ therefore seems to be fitted for obtaining a maximum fertility.

\title{
Changes in the body composition of nulliparous sow during the reproductive cycle : effect of the dietary protein level during gestation
}

\author{
P.H. DUEE, B. DESMOULIN \\ I.V.R.A., Station de Recharches sur l'Elevase des Porcs, \\ Centre de Rennes-Saint-Gilles, F 35590 L'Hermitage
}

An experiment was made on 40 nulliparous Large White sows distributed into 2 groups according to the protein lcvel of the gestation diet $(2 \mathrm{~kg}$ per day of a diet containing $10 \mathrm{or}$ 14 p. 100 protein). During lactation, the animals received a diet containing 14 p. 100 protein according to a daily feed supply of $5.1 \mathrm{~kg}$.

In each group we compared the body composition of the animals at different physiological stages (non-pregnant, post-partum, lactating, post-weaning) and for an equivalent carcass weight $(118 \mathrm{~kg})$, except during lactation $(103 \mathrm{~kg})$.

The measures performed involved the composition of half carcass cuts, either muscle rich (loin, ham) or fat rich (backlat, leaf fat), determination of the specific gravity of ham and loin + backfat measurement of backfat thickness at different sampling sites and of the eye muscle area (at the level of the 13th rib). The physical characteristics of the meat were tested by determination of $\mathrm{pH}$ in 3 muscles, 45 minutes and 24 hours after slaughter and by messurement of the water binding capacity.

At farrowing, the rise in the protein supply during gestation increased the muscle mass at the expense of the fat mass (loin in p. 100 of net weight : 30 to 32.7 ; eye muscle area, $\mathrm{cm}^{*}: 37.9$ to 39.6 ; loin + backfat specific gravity : 1.029 to 1.047$)$. This increase was not observed in non pregnant sows in which the fat content tended to increase with the largest protein supply (backfat : p. 100 weight : $14.8-17.15$; specific gravity of eye muscle : 1.035 to 1.031 ). Accordingly, only a dietary protein level of $14 \mathrm{p}$. 100 led to a larger muscle deposition in pregnant sows as compared to non pregnant sows.

During lactation (at 21 days) a large mobilization of muscle masses was observed in the sows of the 2 groups (eye muscle area $\mathrm{cm}^{2}$, at 14 p. 100 protein : from 39.6 to 31.0 ; at 10 p. 100 protein : from 37.9 to 26.3 ); fat deposition was only affected in the group receiving 10 p. 100 protein during gestation (side backfat thickness : from 32 to $26.4 \mathrm{~cm}$ ).

The effect of the gestation diet on the body composition of the animals was also roticed after weaning. 